\title{
Effectiveness of emotional self-regulation on tolerating distress and mindfulness skills in the patients suffering from migraine
}

\author{
Zahra Parsi Nezhad ${ }^{1}$, Azam Ashori' ${ }^{2}$, Moslem Mahdi Khanloo ${ }^{2}$ \\ 1-Master of Clinical Psychology, Department of Psychology, Zanjan Branch, Islamic Azad University, Zanjan, Iran \\ (Corresponding Author). $\quad$ E-mail: Parsinejad64@yahoo.com \\ 2- Master of Clinical Psychology, Department of Psychology, Zanjan Branch, Islamic Azad University, Zanjan, \\ Iran.
}

Received: 02/03/2020

Accepted: 19/05/2020

\begin{abstract}
Introduction: Migraine has the potential to influence the patients cognitively, emotionally and psychologically in addition to causing physical problems; therefore, applying appropriate psychological therapies can decrease these damages.

Aim: The present study was conducted to investigate the effect of emotional self-regulation on tolerating distress and mindfulness skills in the patients with migraine.

Method: The present study was quasi-experimental with pretest, posttest and control group design. The statistical population in the current study was patients with migraine who referred to therapy centers in the city of Zanjan in the summer of 2019. 30 patients with migraine were selected through convenient sampling method and they were randomly put into experimental and control groups (each group of 15 patients). The experimental group received ten seventy-fiveminute sessions of emotional self-regulation therapy. The questionnaires applied in the present study included distress tolerance and mindfulness skills. The data were analyzed through MANCOVA method.

Results: The results indicated that emotional self-regulation therapy has significant effect on tolerating distress $(\mathrm{F}=62 / 08, \mathrm{P} \leq 0 / 0001)$ and mindfulness skills $(\mathrm{F}=26 / 83, \mathrm{P} \leq 0 / 0001)$ in the patients with migraine patients. The effect sizes of this therapy on tolerating distress and mindfulness skills were $65 \%$ and $52 \%$ respectively.

Conclusion: According to the results of the present study it can be concluded that the emotional self-regulation therapy can be used as an efficient method to improve tolerating distress and mindfulness skills in migraine patients through applying techniques such as recognizing emotions, managing them, and training abreaction.
\end{abstract}

Keywords: Emotional regulation, Tolerating distress, Mindfulness, Migraine headaches

How to cite this article : Parsi Nezhad Z, Ashori A, Mahdikhanloo M. A survey on the efficacy of emotional self-regulation on tolerating distress and mindfulness skills in the people suffering from migraine. Shenakht Journal of Psychology and Psychiatry. 2020; 7 (3): 136-149 . URL: http://shenakht.muk.ac.ir/article-1-842-fa.pdf

Copyright (C) 2018 the Author (s). Published by Kurdistan University of Medical Sciences. This is an open access article distributed under the terms of the Creative Commons Attribution-Non Commercial License 4.0 (CCBY-NC), where it is permissible to download, share, remix, transform, and buildup the work provided it is properly cited. The work cannot be used commercially without permission from the journal. 


\title{
اثربخشى درمان خودنظم جويى هيجانى بر تحمل يريشانى و مهارتهاى ذهن آكاهى افراد مبتلا به سردردهاى ميكرنى
}

\author{
زهرا پارسىنزاد'، اعظم عاشورى'، مسلم مهدىخانلو' \\ 1.كارشناسى ارشد روانشناسى بالينى، گروه روانشناسى، واحد زنجان، دانشكاه آزاد اسلامى، زنجان، ايران (مولف مسئول). \\ ايميل:yahoo.com \\ r. كارشناسى ارشد روانشناسى بالينى، گروه روانشناسى، واحد زنجان، دانشكاه آزاد اسلامى، زنجان، ايران. \\ تاريخ دريافت مقاله:
}

جكيده

مقدمه: سردردهاى ميكرنى علاوه بر مشكلات جسمانى، مى تواند فرايندهاى شناختى، هيجانى و روانشناختى بيماران را نيز متأثر سازد كه ضرورى است با بكار گيرى درمانهاى روانشناختى مناسب نسبت به كاهش اين آسيب هها اقدام شود.

هدف: يثوهش حاضر با هدف بررسى اثربخشى درمان خودنظمجويى هيجانى بر تحمل بريشانى و مهارتهاى ذهن آكاهى افراد مبتلا به سردردهاى ميكرنى انجام گرفت.

روش: يزوهش حاضر نيمهآزمايشى با طرح بيشآزمون- بس آزمون با گروه گگ اه بود. جامعه آمارى اين يثزوهش افراد مبتلا به

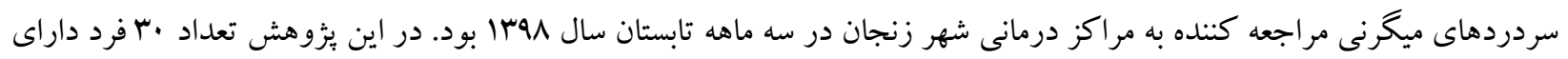

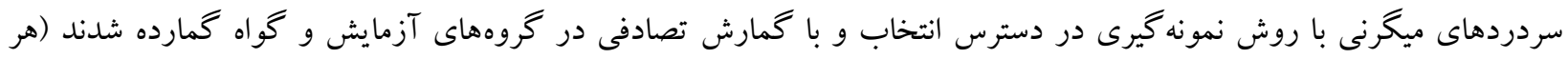

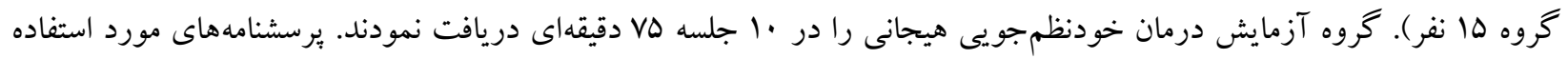

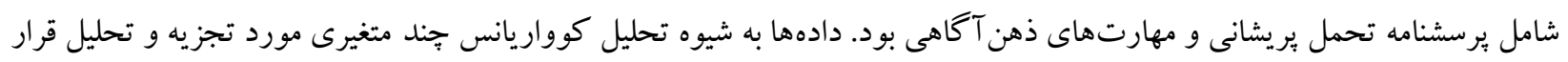
كرفت.

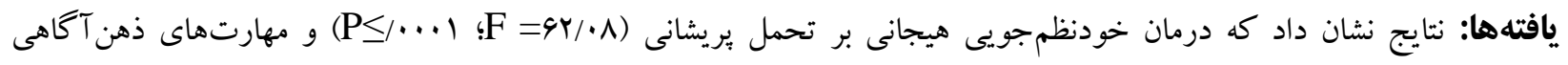
افراد مبتلا به سردردهاى ميكرنى تأثير معنادار دارد. مقدار تاثير اين درمان بر ميزان تحمل بريشانى و و

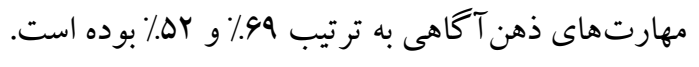

نتيجه كيرى: براساس نتايج حاضر مىتوان كفت درمان خودنظم جويى هيجانى با بهره كيرى از تكنيك هاى همجِون شناخت هيجانات،

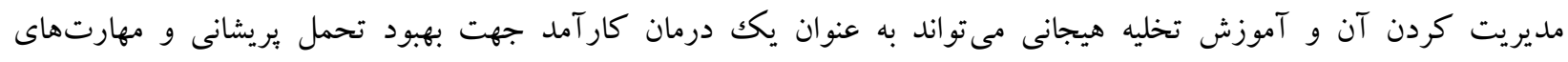
ذهن آكاهى افر اد مبتلا به سردردهاى ميخرنى مورد استفاده گيرد. كليدوازهها: خودنظمجويى هيجانى، تحمل يريشانى، ذهن آكاهى، سردردهاى ميخرنى 


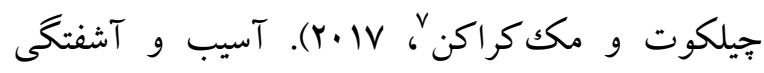
روانشناختى در اين بيماران نيز مىتواند با كاهش تحمل

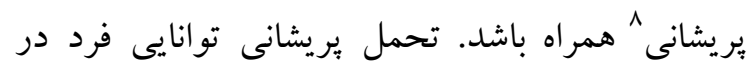
تجربه و تحمل حالات هيجانى منفى تعريف شده است

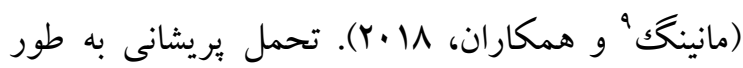

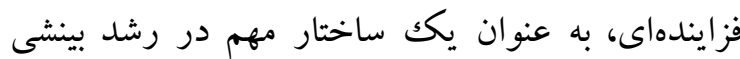
جديد درباره شروع و ابقاى آسيبهاى روانى و همجنين بيشخيرى و درمان مشاهده شده است (زلن اسكاى،

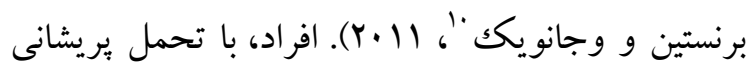
بايين در يكك تلاش غلط براى مقابله با هيجانات منفى ورنى

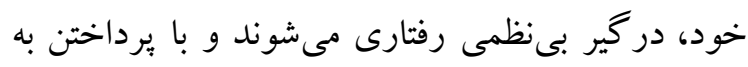
برخى رفتارهاى مخرب درصدد تسكين درد هيجانى

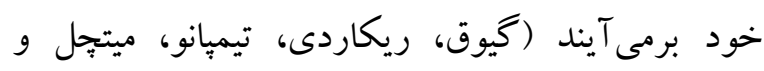

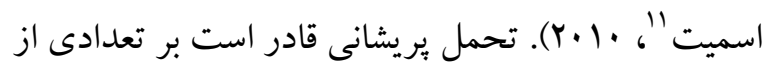
فرايندهاى مرتبط با خودنظمجويى همجيون توجه،

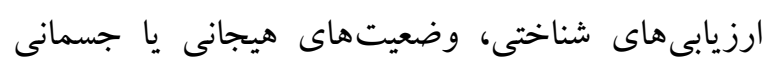
آشفتكى زا تأثير نهاده و اثر آنها را تعديل نمايد. افراد با هاب تحمل يريشانى بالا براى اجتناب از احساسات و عواطف له

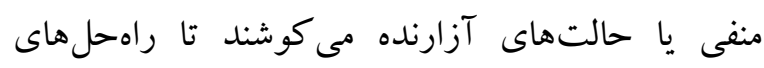

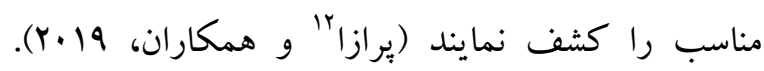
علاوه بر اين، افراد با تحمل بريشانى نسبت به افراد با تحمل بريشانى بايين، براى مشكلات جسمانى و محيطى مىتوانند به شكل هنجارمندترى بِاسخ انطباقى بيابند

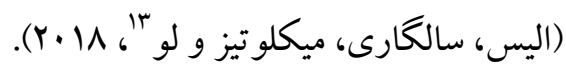
علاوه بر تحمل بريشانى، سردردهاى ميگرنى سبب در آميختكى بردازش شناختى و عمل در بيماران شده و

7- Almarzooqi, Chilcot, McCracken

8 - Distress tolerance

9 - Manning

${ }^{10}$ - Zvolensky, Bernstein, Vujanovic

${ }^{11}$ - Keough, Riccardi, Timpano, Mitchell, Schmidt

12 - Peraza

${ }^{13}$ - Ellis, Salgari, Miklowitz, Loo

\section{مقدمه}

اختلالات عصبى ناتوان كننده متعدى وجود دارد مى تواند فرد را با مشكلات فراوانى مواجه سازد. يكى از انواع اين اختلالات كه از شايعترين شكايات بز شكى نيز به شمار

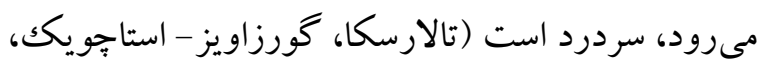
ميجالاكك، زلجكوسكا و هاداس'، (Y.|F). سردرد ميگرنى ' نوعى از سردرد است كه ضرباندار و تكرار شونده بوده و در ناحيه گيجگاهى و يا بيشانى ظاهر شده و به هنگام حملات، با تهوع، استفراغ وكريز از نور و صدا

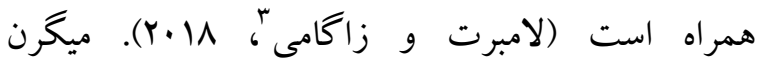
كلاسيك (همراه با اورا يا علائم هشدار دهنده و ميخرن شايع (بلدون اورا) انواع اين سردرد محسوب مىشوند

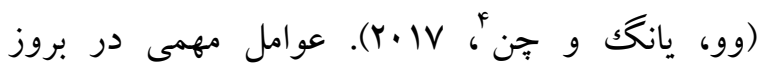
سردردهاى ميگرنى دخيل است كه از مهمترين آنها مىتوان به كاهش اثر مكانيسمهاى مهارى در انتقال درد در سيستم اعصاب مركزى، انبساط عروقى و نيز التهاب نوروزنيك اشاره كرد (بوهم، استان كامييانو و رزونه

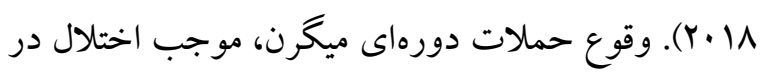
عملكرد بيمار كشته كه از جمله آنها مىتوان به عدم تمركز و امتناع از هركونه فعاليت شخصى و اجتماعى و غيبتهاى طولانى مدت از محل كار و تحصيل، تأثير بر خلقوخو و متعاقب آن اختلال در روابط فرد با اطرافيان

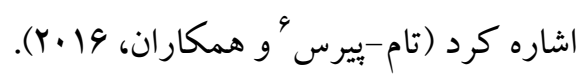

بروز سردردهاى ميخرنى علاوه بر آسيبهاى جسمانى

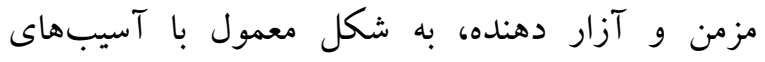
روانشناختى و هيجانى نيز همراه است (المرزوقى،

\footnotetext{
1- Talarska, Zgorzalewicz-Stachowiak, Michalak, Czajkowska, Hudas

${ }^{2}$ - Migraine headache

3 - Lambert, Zagami

${ }^{4}$ - Wu, Yang, Chen

5 - Bohm, Stancampiano, Rozen

${ }^{6}$ - Tomé-Pires
} 
كرفته شده است كه تا به بهبود مؤلفههاى روانشناختى اين بيماران يارى رسانده شود. يكى از اين روشها،

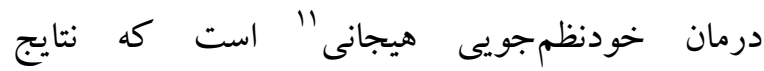
يزوهشهاى بيشين نشان از كارآيى اين درمان داشته است (دهقانى، حكمتيانفرد، كامران، شريفى، نيكك خواه و غضنفرى، هوبا؛ احمدى، سهرابى و برجعلى، وMTV؛ شاملى، مهرابىزاده هنرمند، نعامى و

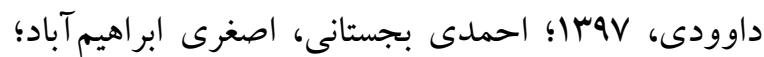

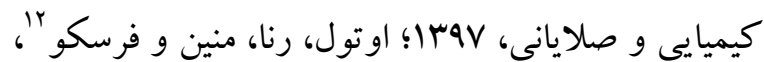

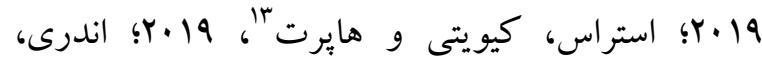

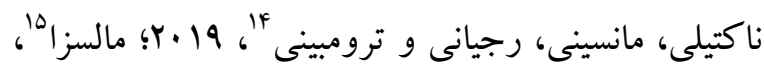

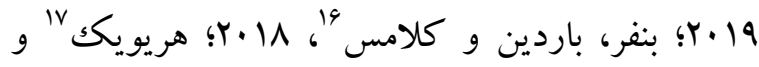

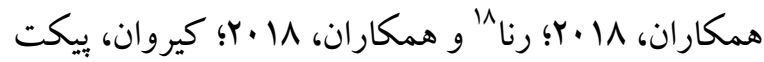

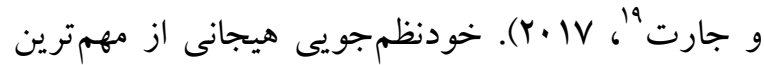
مدلها در خصوص نقش سيستمهاى عصبى در مهار هيجان است. جنانكه اين دسته از مدلها در تنظيم كنشهاى هيجانى به فرايندهاى گوناكون شناختى مؤثر

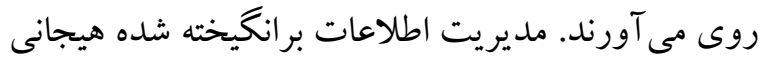

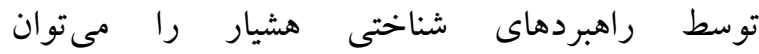

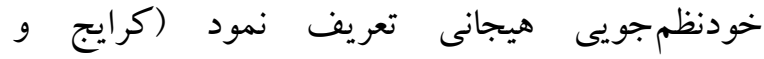

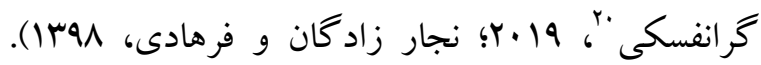
فر آيندهاى خودنظمجويى هيجانى افراد، بر دريافت و ادراكك اينكه جه هيجاناتى را تجربه مى كنند، جه موقع آنها را تجربه مى كنند و جّگ تأثير مى گذارد و اين فر آيند به صورت ساختار وسيعى در

${ }^{11}$ - Emotion regulation therapy

${ }^{12}$ - O’Toole, Renna, Mennin, Fresco

13 - Strauss, Kivity, Huppert

${ }^{14}$ - Andrei, Nuccitelli, Mancini, Reggiani

15 - Malesza

${ }^{16}$ - Benfer, Bardeen, Clauss

17. Herwig

18 - Renna

${ }^{19}$ - Kirwan, Pickett, Jarrett

${ }^{20}$ - Kraaij, Garnefski
ذهن آكَاهى' و مهارت هاى ذهن آكاهى ' آنها را كاهش

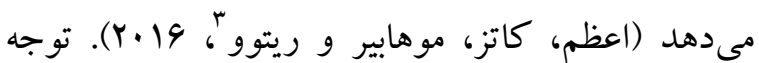
كردن به شيوهاى خاص، هدفمند، در زمان حاضر و خالى از قضاوت، ذهن آكاهى تعريف مىشود (كروسكا، ميلر،

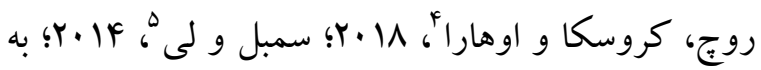
نقل از اصلى آزاد، منشئى و قمرانى، دوسا). همجنين ذهن آكاهى نوعى روش سيستمى و فشرده است كه به منظور افزايش توجه، آكاهى و بينش و نيز كسب انواع جديدى از كنترل و خردمندى بر بايه توانمندىهاى درونى براى رسيدن به آرميدگى به كار مىرود (سگال،

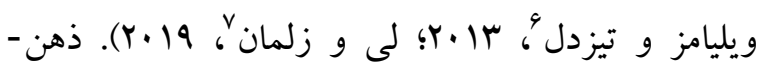
آكاهى روشى است براى تسكين دردها و غنا بخشى و

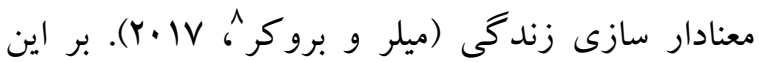
اساس، شواهد و ادبيات تحقيق نمايانگر اثرات مفيد ذهن آكاهى در شناخت خود و بهبود رفتارهاى فردى، اجتماعى و خانوادگى است (هوبٍ وود و اسجاتج؛

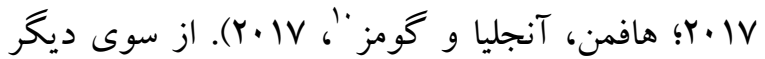
ذهن آكَاهى با فرايندهاى شناختى همجِون كاركردهاى اجرايى مغز را نيز تحت تأثير قرار دهد كه بر اين اساس برخوردارى از مهارتهاى ذهن آكاهى با برنامهريزى، سازماندهى و كنترل رفتار بالاتر همراه است (فرهادى، اصلى آزاد و شكرخدايى، لو اس I). علاوه بر درمانهاى فيزيولوزيكى جهت كاهش درد در بيماران مبتلا به سردردهاى ميخرنى، روشهاى درمانى و آموزش روانشناختى مختلفى نيز براى اين افراد بكار

\footnotetext{
1- Mindfulness

2 - Mindfulness skills

3 - Azam, Katz, Mohabir, Ritvo

4- Kroska, Miller, Roche, Kroska, O’Hara

5 - Semple, Lee

6- Segal, Williams \& Teasdale

7. Lee, Zelman

8 - Miller, Brooker

9 - Hopwood, Schutte

10 - Hofmann, Angelina, Gomez
} 


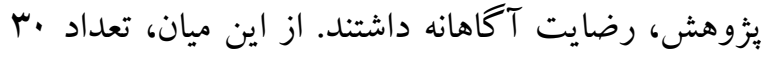
نفر به شيوه نمونه گيرى داوطلبانه انتخاب شدند. بدين

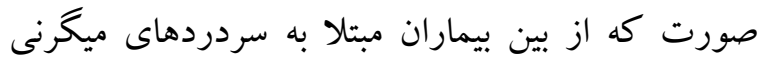
مراجعه كننده به مراكز درمانى شهر زنجان، تعداد .ب نفر به شكل داو طلبانه انتخاب شدند. شيوه انتخاب نمونه بدين صورت بود كه با مراجعه به مراكز درمانى بيماران داراى

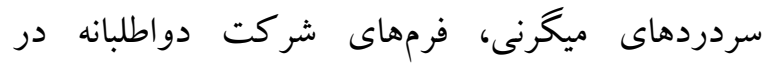
يُزوهش در بين بيماران توزيع و بِ از جمع آورى، تعداد • س نفر از اين بيماران انتخاب و به صورت تصادفى در گروههاى آزمايش و گ گواه گمارده شدند (ها نفر در كروه آزمايش و ها نفر هم در گروه گواه). قبل از ارائه درمان خودنظمجويى هيجانى، يرسشنامهاى يثزوهش به

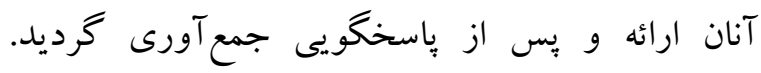
ملاككهاى ورود به بثزوهش شامل داشتن بيمارى ميكرن به تشخيص متخصص، عدم برخوردارى از آسيبهاى

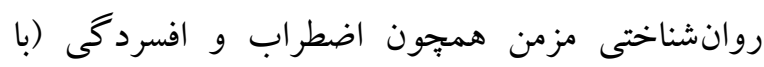
توجه به خوداظهارى و مصاحبه بالينى)، نداشتن بيمارى جسمى حاد و مزمن ديخر و اعلام رضايت و آمادكى بهى جهت شركت در يثوهش بود. همجينين ملاككهاى خروج از ئزوهش شامل داشتن بيش از دو جلسه غيبت، عدم همكارى و انجام ندادن تكاليف مشخص شده در كلاس و عدم تمايل به ادامه حضور در فرايند انجام

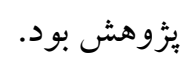

روند اجراى يُزوهش حاضر بدين صورت بود كه يس از

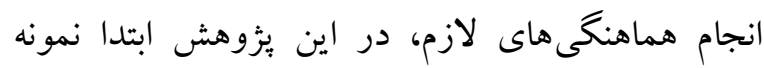
يُزوهش جمع آورى شد. سيس طى جلسه آموزشى روند اجراى ئزوهش و اهداف بسته درمانى براى بيماران

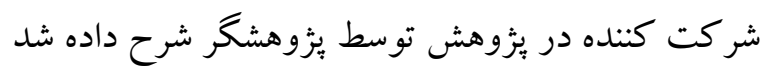
تا اين افراد آكاهى و رضايت لازم جهت شركت در

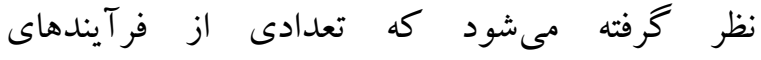
خودنظم جويى, خصيصه هاى زيربنايى و اساسى هيجانات مثل واكنشيذيرى فيزيولوزيايى، اجتماعى، رفتارى، فرايندهاى شناختى و نيز تنظيم تجربه هيجانات راد در خود

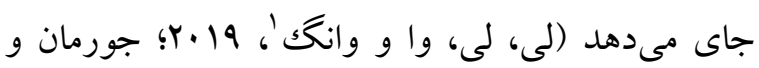

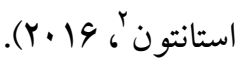
در باب ضرورت انجام يثوهش حاضر مىتوان بيان كرد، با وجود اينكه بيشتر مطالعات انجام شده در زمينه سببشناسى اين بيمارى در جنبه هاى زيستى و و فيزيولوزيكى متمركز بوده است و اين فرايند به تنهايى قادر به توجيه و توضيح علت دقيق اين بيمارى نيست. علاوه بر اين خلأ، وجود عوامل ديخرى در زمينه سببشناسى سردردهاى ميخرنى توجه بثزوهشخران را به به عوامل روانشناختى مؤثر در بيشبينى اين بيمارى جلب

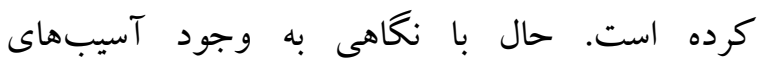
روانشناختى در بيماران مبتلا به سردردهاى ميخرنى و از سويى با نظر به كار آيى درمان خودنظم جويى هيجانى در فروكاستن آسيبهاى شناختى و فيزيولوزيكك افراد مختلف و نيز عدم انجام يزوهشى مشابه، محققين تصميم كرفتند تا تأثير درمان خودنظمجويى هيجانى بر تحمل

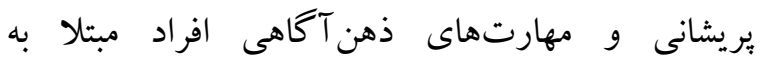
سردردهاى ميخرنى را مورد بررسى و آزمون قرار دهند.

روش طرح يثوهش حاضر، از نوع نيمه آزمايشى با بيش آزمون-

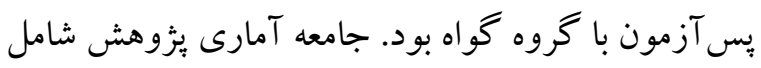
بيماران مبتلا به سردردهاى ميخرنى شهر زنجان در سه به بهو

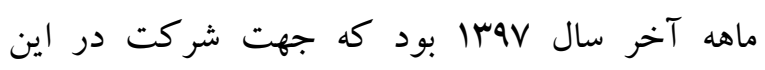

\footnotetext{
1. Li, Li, Wu, Wang

2- Joormann, Stanton
} 
خودنظم جويى هيجانى كراس (Y..V.) بود كه از يزوهش هوايى، كاظمى، حبيبالهى و ايزدىخواه (هوبا) اقتباس شده است. جهت رعايت اخلاق در برزوهش رضايت بيماران براى شركت در برنامه مداخله كسب و از كليه مراحل مداخله آكاه شدند. هم جنين به افراد گروه كواه

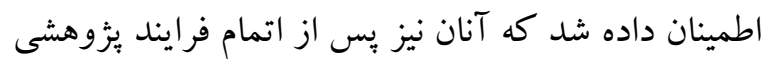
اين مداخلات را دريافت خو اهند نمود. همجِنين به هر دو كروه اطمينان داده شد كه اطلاعات آنها محرمانه باقى مدري مى ماند و نيازى به درج نام نيست.
يثزوهش را اعلام نمايند. در كام بعد همه افراد دو گروه

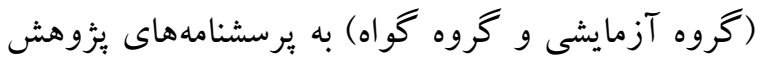

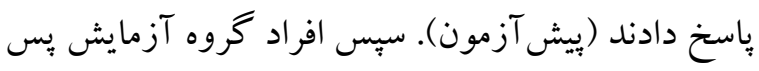
از انتصاب تصادفى در گروهها، مداخله درمان خودنظمجويى هيجانى را در ·ل جلسه VD دقيقهاى در طى دو و نيم ماه به صورت هفتهاى يكك جلسه دريافت و بس از اتمام جلسات آموزشى افراد دو گروه مجدداً به

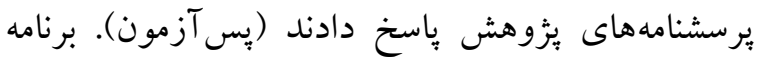
مداخلهاى در بيزوهش حاضر برگرفته از برنامه درمان

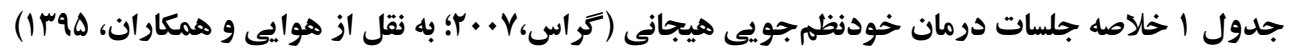

\begin{tabular}{|c|c|}
\hline شرح جلسه & 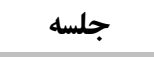 \\
\hline اجراى بيش آزمون، معارفه افراد نمونه يُؤوهش با يكديخر، بيان ضرورت آشنايى و استفاده از تنظيم هيجان در زندگى. & جلسه اول \\
\hline 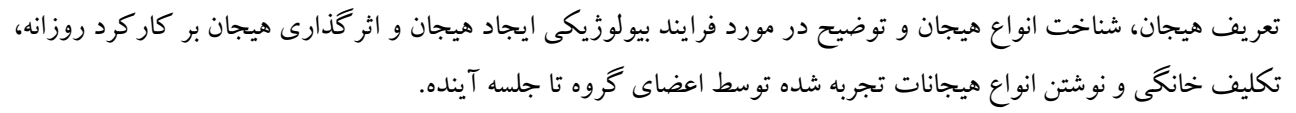 & 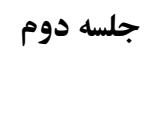 \\
\hline 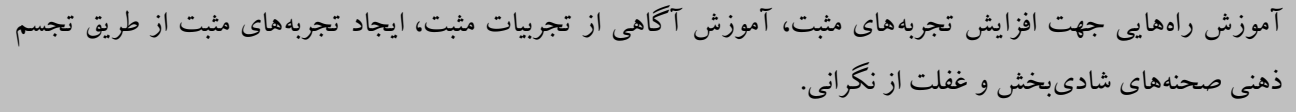 & 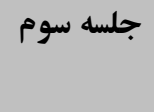 \\
\hline 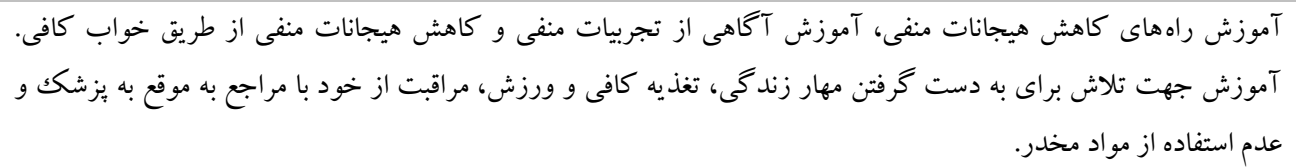 & جلسه \\
\hline رفتارى و فيزيولوز در راستاى شناسايى ارزيابىهاى غلط و واثرات آنها روى حالات هيجانى، آموزش راهبرد باز ارزيابى و تغيير ييامدهاى & 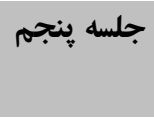 \\
\hline 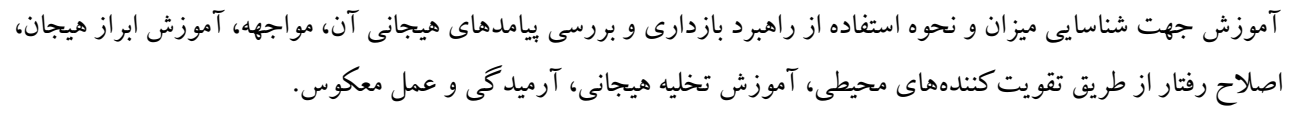 & جلسه ششم \\
\hline توجه Tكاهانه به هيجان فعلى، توجه كامل به هيجان مثبت و منفى خود و يذيرش آن بدون قضاوت و ابراز صحيح هيجان. & جلسه هفتم \\
\hline آبراز مناسب و و بازدارى مجد از ابراز نامناسب هيجانات مثبت و منفى، آموزش ارزيابى از هيجانات و و توجه به ييامدهاى هر هيجان و تلاش براى & جلسه هشتم \\
\hline آموزش تغيير هيجانات منفى از طريق عمل بر خلاف هيجان تجربه شده مانند ترس، عصبانيت و استرس. & جلسه نهم \\
\hline جمعبندى مطالب درمانى جلسات كذشته و اجراى بـ آزمون. & جلسه دهم \\
\hline
\end{tabular}

نرمال بودن توزيع متغيرها، آزمون لوين براى بررسى

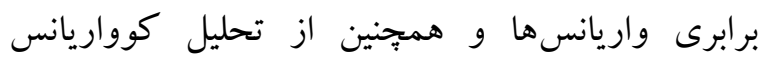
جندمتغيرى براى بررسى فرضيه يخوهش استفاده گرديد.
در اين ئزوهش براى تجزيه و تحليل دادهها از دو سطح آمار توصيفى و استنباطى استفاده شده است. در سطح آمار توصيفى از ميانگين و انحراف استاندارد و در سطح

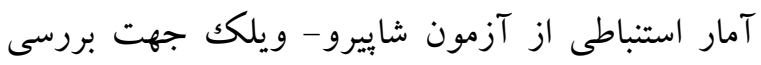


يزؤهش اسماعيلىنسب، اندامىخشك، آزرمى و و

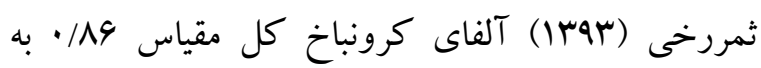

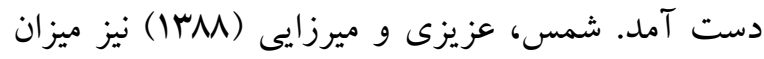

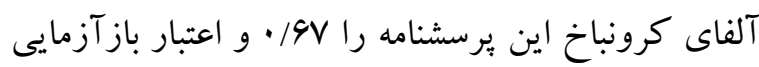

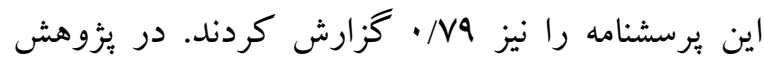
حاضر نيز قابليت اعتماد اين برسشنامه با استفاده از ضريب آلفاى كرونباخ AV/ • به دست آمد.

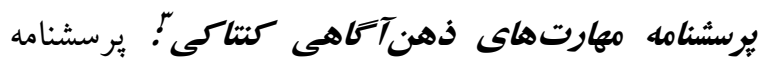

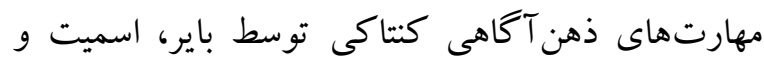

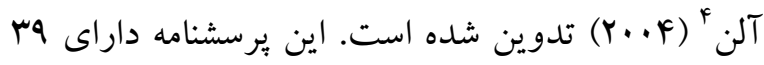
ماده و جهار مؤلفه ذهن آكاهى طراحى شده است كه

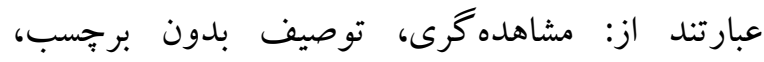

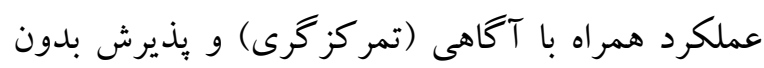
قضاوت. اين زبرسشنامه در يكك طيف ليكرت ينج درجهاى از خيلى به ندرت تا اكثراً (نمره يكك تا ينج)

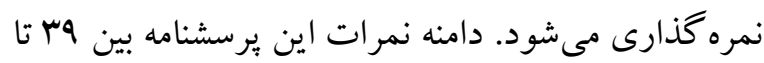
190 است. در اين مقياس فردى كه نمره بالايى را اخذ نمايد به معنى آن است كه ذهن آكاهى بالايى دارد. نتايج

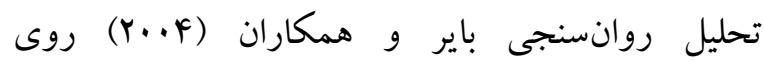

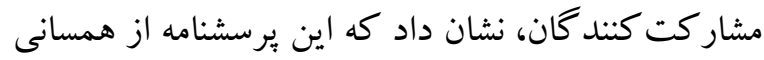
درونى بالايى (T//) برخوردار و نيز ضرايب آلفاى

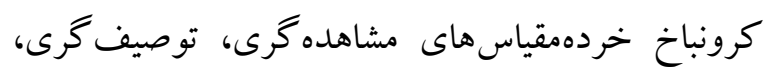

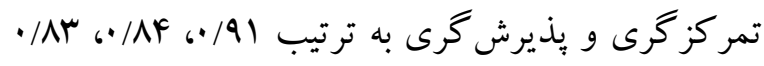

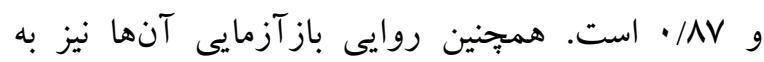

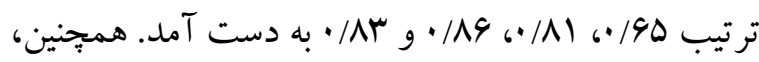

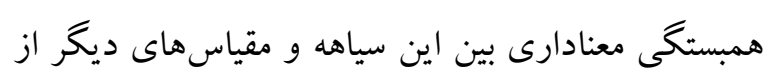
جمله ابزار ارزيابى ذهن آكاهى براون و ريان، سياهه

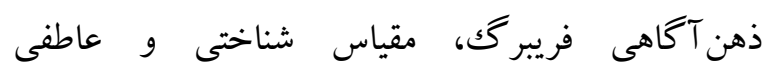

\footnotetext{
3 - Kentaki Inventory mindfulness skills

4. Baer, Smith \& Allen
}

نتايج آمارى با استفاده از نرمافزار آمارى سץ-SPSS مورد تجزيه و تحليل قرار گرفت.

ابز ار برسشنامه تحمل بريشانى': برسشنامه تحمل بريشانى يك

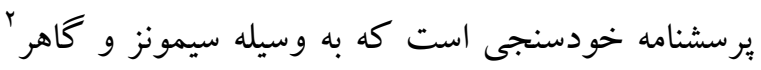

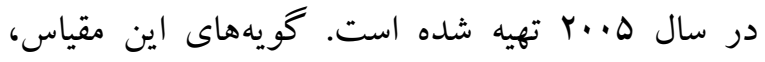
تحمل بريشانى را بر اساس توانمندىهاى فرد براى تحمل

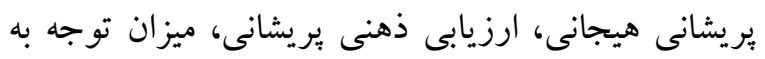
هيجانهاى منفى در صورت وقوع و اقدامهاى تنظيم كننده براى تحمل بريشانى ارزيابى مى كنند. اين مقياس شامل ها يرسش و جهار خردهمقياس تحمل يريشانى هيجانى، جذب شدن به وسيله هيجانهاى منفى، ارزيابى ذهنى بريشانى و تنظيم تلاشها در راستاى كاهش يريشانى مىشود. گويههاى اين مقياس بر اساس مقياس ينج درجهاى ليكرت نمره كذارى مىشوند. نمرههاى بالا در اين مقياس نشان دهنده تحمل يريشانى بالا است. در

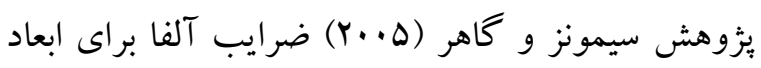
تحمل بريشانى هيجانى، جذب شدن به وسيله هيجانات منفى، برآورد ذهنى يريشانى و تنظيم تلاشها براى

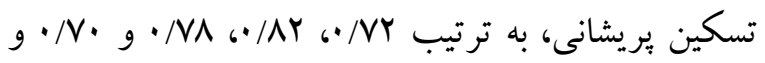

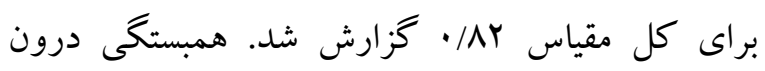
طبقهاى پِ از گذشت شش ماه، 191/· بود. همجنين، مشخص شده كه اين مقياس داراى درستى آزمايى ملاكى و همخراى اوليه خوبى است. اين مقياس با بذيرش خلق رابطه مثبت و با مقياس هاى راهبردهاى مقابله اى استفاده از الكل و مارى جوانا و همجنين استفاده از آنها براى

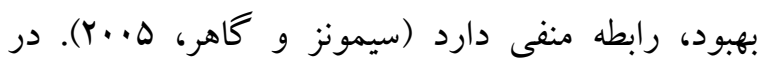

\footnotetext{
1- Distress tolerance Questionnaire

2- Simons \& Gaher
} 
كه در اين بين دامنه سنى TV تا •r سال داراى بيشترين فراوانى بود (Yس درصد). از طرفى اين افراد داراى سطح تحصيلات سيكل تا فوق ليسانس بودند كه در اين بين سطح تحصيلات ليسانس بيشترين فراوانى را به خود اختصاص داده بود (·r درصد). هم:جنين بيشتر اين افراد

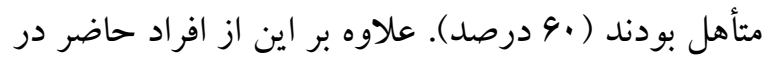
يخوهش IV نفر (معادل ه/99 درصد) زن و سا نفر

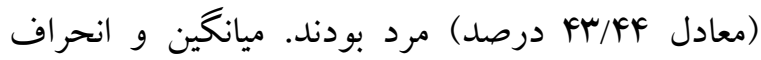

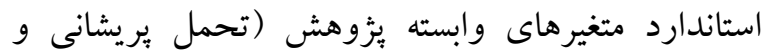
مهارتهاى ذهن آكاهى افراد داراى سردردهاى ميكرنى) در مراحل ييش آزمون و بس آزمون، به تفكيك دو گرووه آزمايش و گواه، در جدول r، ارائه شده است تا بر اساس آن بتوان تغييرات ميانخين نمرات متغيرهاى تحمل ير يشانى و مهارتهاى ذهن آكاهى رادو گروه آزمايش و

$$
\text { كو اه مشاهلده نمود. }
$$

ذهن آكاهى فلدمن و :برسشنامه ذهن آكاهى جادويك وجود دارد (باير، اسميت، هإيكينز، كريتماير و كانى،

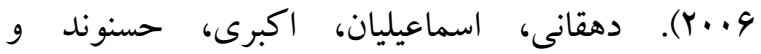
نيككمنش، (Irqf) در ايران خصوصيات روانسنجى اين يرسشنامه را مورد بررسى قرار دادند. يافتههاى اين

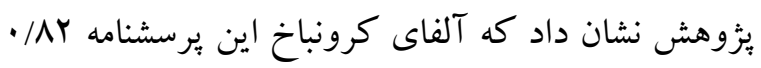

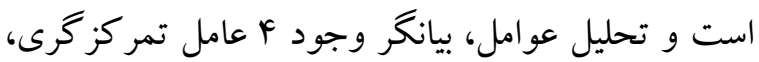

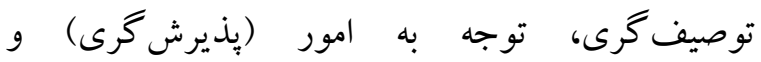
مشاهده Fرى در اين سياهه بود كه اين عوامل، درصد از واريانس كل آزمون را تبين مى كند. اعتبار

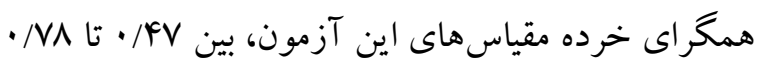
به دست آمد. بيايايى اين برسشنامه در بئوهش حاضر با استفاده از ضريب آلفاى كرونباخ •^/ • به دست آمد.

\section{يافتهها}

يافته هاى حاصل از دادههاى جمعيت شناختى نشان داد كه افر اد نمونه يُزوهش داراى دامنه سنى Y تا ها Fال سال بودند

\begin{tabular}{|c|c|c|c|c|c|}
\hline \multicolumn{2}{|c|}{ ״ِ آزمون } & \multicolumn{2}{|c|}{ بيش آزمون } & \multirow[t]{2}{*}{ كروهol } & \multirow[t]{2}{*}{ مؤلفه ها } \\
\hline انحراف معيار & ميانكين & انحراف معيار & ميانكين & & \\
\hline$r / l$ & $19 / 4$. & $r / \Delta$. & $11 / 19$ & گروه آزمايش & \multirow[t]{2}{*}{ تحمل بريشانى } \\
\hline$r / \wedge 9$ & $1 Y / Y 9$ & $r / N r$ & $11 / N$ & كروه گواه & \\
\hline $\mid r / \cdot F$ & $\wedge \varepsilon / \Delta r$ & $\mid r / F A$ & $V 1 / r e$ & كروه آزمايش & \multirow{2}{*}{ مهارتهاى ذهن آكاهى } \\
\hline $9 / \Gamma F$ & $V 1 / 49$ & $Q / 4 V$ & $v \cdot / k$. & گروه گواه & \\
\hline
\end{tabular}

لوين استفاده شده است. نتايج نشان داده است در مرحله پس آزمون در متغيرهاى تحمل بريشانى و مهارتهاى ذهن آكاهى بيش فرض همخنى واريانس دها برقرار بوده

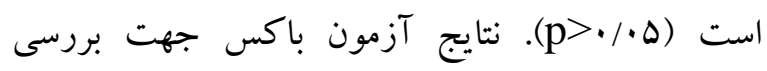
همسانى ماتريسهاى واريانس - كواريانس نشان داد كه

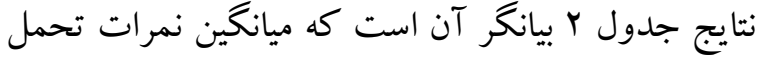

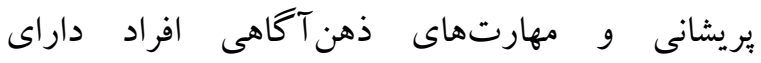
سردردهاى ميخرنى در گروه آزمايش در اثر دريافت درمان خودنظمجويى هيجانى افزايش بيدا كرده است. جهت بررسى بيشفرض همخنى واريانسها، از آزمون 
با متغير گروهبندى در مرحله پس آزمون در متغيرهاى تحمل بريشانى و مهارتهاى ذهن آكاهى معنادار نبوده

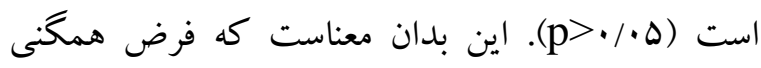

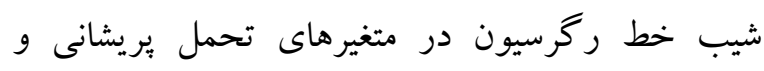
مهارتهاى ذهن Tكاهى برقرار بوده است. پيس از اطمينان از رعايت بيشفرضهاى مورد نياز تحليل آزمون كوواريانس، نتايج اين آزمون ارائه شده است.
در مرحله بِ آزمون بيشفرض ماتريسهاى واريانس -

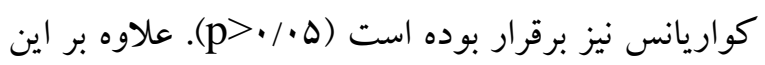

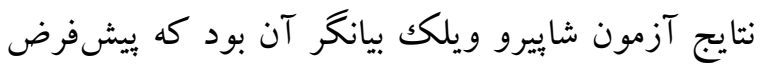

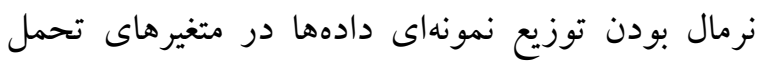

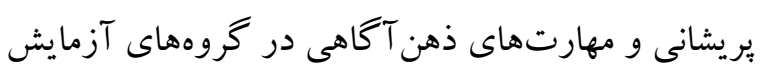

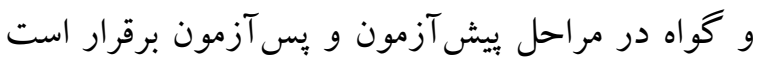

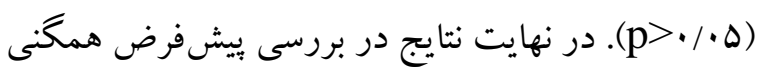
شيب خط رگرسيون مشخص شد كه تعامل بيش آزمون

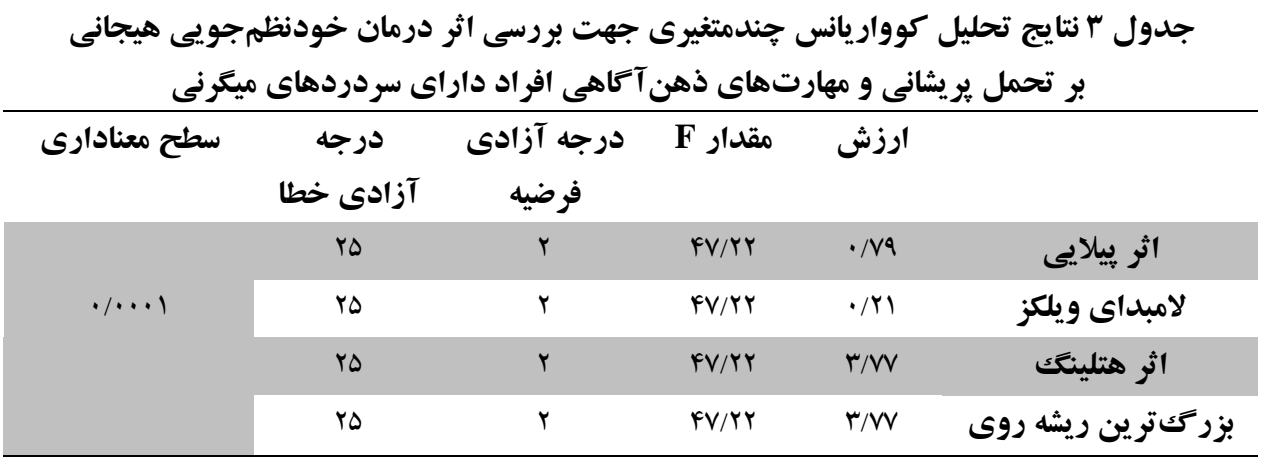

داشته باشد؛ بنابراين جهت بررسى اين نكته كه معنادارى

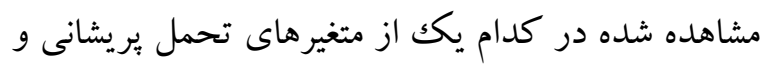

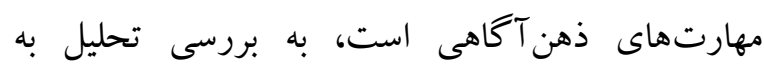
كوواريانس تككمتغيرى برداخته شد.
با معنادارى آزمون كوواريانس جندمتغيرى اين نتيجه حاصل مى گردد كه بايد حداقل در يكى از متغيرهاى

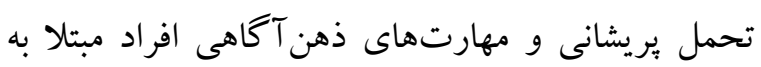

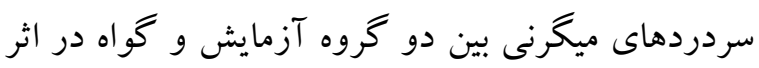
ارائه درمان خودنظمجويى هيجانى تفاوت معنادار وجود

جدول ^ نتايج تحليل كوواريانس تكمتغيرى جهت بررسى اثر درمان خودنظمجرويى هيجانى

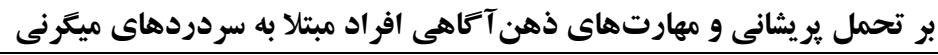

\begin{tabular}{|c|c|c|c|c|c|c|c|c|}
\hline 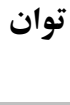 & اندازه & معنادارى سطح & Fقدار & مجذورات & آدزادى درجه & مجذموع مجدورات & متغير & منبع تغيير \\
\hline 1 & .199 & $\cdot / \cdots \cdot 1$ & $9 Y / \cdot 1$ & $111 / \cdot r$ & 1 & $111 / \cdot r$ & تحمل بريشانى & \multirow{2}{*}{ خودنظم جتويى هيجانى مستقل (درمان) } \\
\hline 1 & $\cdot / \Delta r$ & $\cdot / \cdots 1$ & rq/Ar & $|\Delta F 9 / N|$ & 1 & $|\Delta F q / V|$ & مهارتهاى ذهن آكاهى & \\
\hline & & & & I/VA & rq & $49 / 49$ & تحمل بريشانى & \multirow[t]{2}{*}{ خطا } \\
\hline & & & & $\Delta V / V F$ & rq & $10 \cdot 1 / \pi$ & مهارتهاى ذهن آكاهى & \\
\hline & & & & & $r$. & strr & تحمل بريشانى & \multirow[t]{2}{*}{ كل } \\
\hline & & & & & $r$. & I9YIMA & مهارتهاى ذهن آكاهى & \\
\hline
\end{tabular}




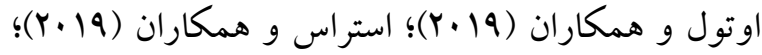

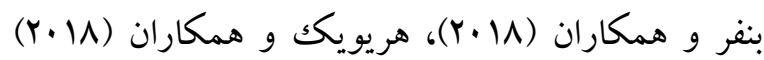
همسو بود. اين بزوهشخران به اتفاق نشان دادهاند كه درمان خودنظمجويى هيجانى مىتواند منجر به بهبود مؤلفه هاى روانشناختى افر اد مختلف شود. در تبيين يافته حاضر مبنى بر تأثير درمان خودنظمجويى هيجانى بر تحمل بريشانى افراد مبتلا به سردردهاى ميكرنى مىتوان كفت درمان خودنظم جويى هيجانى به افراد مبتلا به سردردهاى ميخرنى يارى مىرساند تا برانگيختخى هيجانى و هيجانهاى منفى را تنظيم نمايند، احساسات خود را درك نموده و به طرز اثربخشى با آن برخورد كنند كه اين فرايند باعث مىشود تا آنان در فرايندهاى ادراكى و هيجانى خود تغييرات مفيدى را به وجود آورند و علاوه بر بازدارى برانگيختخى هيجانى، در برابر افكار و هيجانات منفى نيز مقاومت نمايند. بازدارى هيجانات و مديريت هيجانهاى منفى نيز به شكل طبيعى منجر به بهبود تحمل بريشانى در اين افراد مىشود. علاوه بر اين درمان خودنظم جويى هيجانى سبب مىشود تا افراد در بيان هيجاناتشان در برابر به توقعات محيطى هشيارانه و ناهشيارانه تعديل ايجاد نمايند (هريويكك و همكاران،

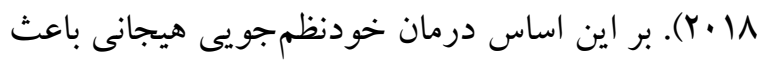
مىشود افراد مبتلا به سردردهاى ميخرنى بر روى نوع، زمان و جِكونگى تجربه هيجان و بيان آن، تغيير طول دوره يا شدت فرايندهاى رفتارى و تجربى و يا جسمانى هيجانها تغييراتى را اعمال نمايد. همجنين بايد اشاره كرد، خودنظمجويى هيجانى با بكارگيرى راهبردهاى

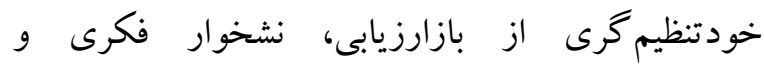

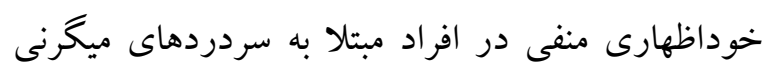

با توجه به نتايج جدول F) ارائه متغير مستقل (درمان خودنظمجويى هيجانى) توانسته منجر به ايجاد تفاوت معنادار ميانگين نمرات متغيرهاى وابسته (تحمل بريشانى و

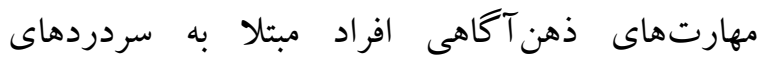

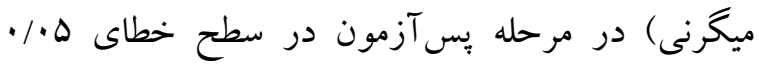
كردد. لذا اين نتيجه حاصل مىشود كه با كنترل متغير مداخله گر (ييش آزمون)، ميانگين نمرات متغيرهاى تحمل

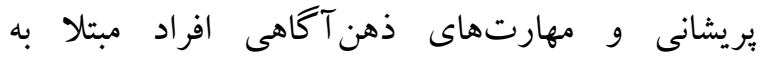
سردردهاى ميخرنى با ارائه درمان خودنظم جويى هيجانى دجار تغيير معنادار شده است. جهت تغيير نيز بدان صورت بوده است كه درمان خودنظمجويى هيجانى توانسته منجر به افزايش تحمل بريشانى و مهارتهاى ذهن آكاهى افراد مبتلا به سردردهاى ميگرنى شود. مقدار تأثير درمان خودنظمجويى هيجانى بر ميزان تحمل

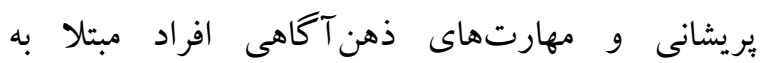
سردردهاى ميكرنى به ترتيب 199/ • و Or/ • بوده است. اين بدان معناست كه به ترتيب 99 و ه ه درصد تغييرات متغيرهاى تحمل يريشانى و مهارت هاى ذهن آكاهى افراد مبتلا به سردردهاى ميكرنى توسط ارائه متغير مستقل (درمان خودنظم جويى هيجانى) تبيين مىشود.

يثوهش حاضر با هدف بررسى اثربخشى درمان خودنظمجويى هيجانى بر تحمل يريشانى و مهارتهاى ذهن آكاهى افراد مبتلا به سردردهاى ميگرنى انجام كرفت. يافته اول بيزوهش نشان داد كه درمان خودنظم جويى هيجانى منجر به بهبود تحمل بريشانى افراد مبتلا به سردردهاى ميخرنى شده است. يافته حاضر با

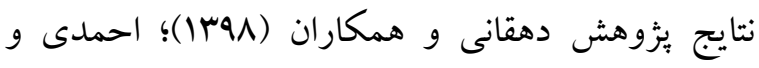

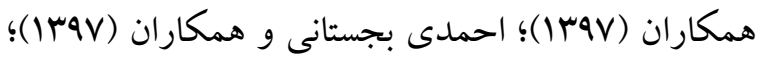


دنبال تسكين فورى هيجانات منفى و يا اجتناب از آنها نباشند؛ به عبارت ديخر اگرجّه فرد نمىتواند شرايط بيمارى خود را تغيير دهد؛ ولى مىتوانند شدت واكنشهاى هيجانى خود را نسبت به موقعيتهاى تنش زا و رويدادهاى زندگى تغيير دهند. با دقت در اين فرايند مشخص مىشود كه درمان خودنظمجويى هيجانى تلاش دارد تا افراد مبتلا به سردردهاى ميخرنى را از آميختخى با هيا هيجانات، افكار و احساسات منفى باز دارد. گسلش از

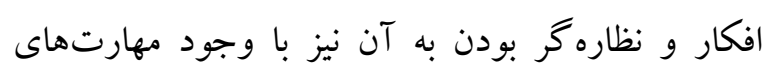
ذهن آكاهى ميسر مىشود. از همين روست كه درمان خودنظمجويى هيجانى مىتواند منجر بهبود مهارتهاى ذهن آكاهى افر اد مبتلا به سردردهاى ميخرنى شود.

\section{نتيجه كيرى}

درمان خودنظم جويى هيجانى مىتواند با بهره راههايى همجيون افزايش تجربه هاى مثبت، آموزش آكاهى از تجربيات مثبت، ايجاد تجربههاى مثبت از طريق تجسم ذهنى، آموزش راههاى كاهش هيجانات منفى، كاهش هيجانات منفى، توجه آكاهانه به هيجان فعلى، توجه كامل به هيجان مثبت و منفى خود و ويذيرش آن بلدون قضاوت توانسته بود منجر به بهبود تحمل يريشانى و

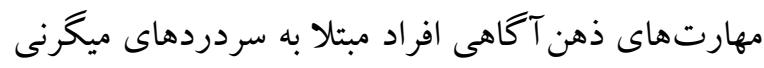
شود كه بر اين اساس مىتوان بيشنهاد كاربردى بيزوهش

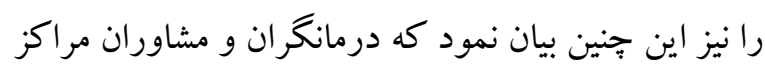

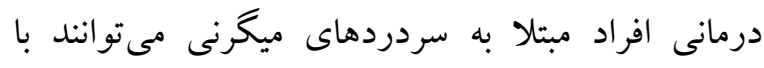
بهرهگيرى از درمان خودنظمجويى هيجانى وضعيت شناختى اين بيماران را بهبود بخشند. محدود بودن دامنه تحقيق به افراد مبتلا به سردردهاى ميكرنى شهر زنجان؛

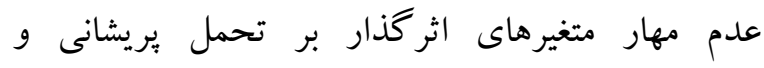
مهارت هاى ذهن آ كاهى افراد مبتلا به سردردهاى ميكرنى،
جلو گيرى كرده و اين فرايند نيز منجر به بهبود توان مقابلهاى و تحمل بريشانى در آنها مىشود. يافته دوم يثزوهش نشان داد كه درمان خودنظمجويى هيجانى منجر به بهبود مهارتهاى ذهن آكاهى افراد مبتلا به سردردهاى ميخرنى شده است. يافته حاضر با نتايج يثزوهش كرمى و همكاران (1) (1)؛؛ شاملى و همكاران (Y (1))؛ اندرى و همكاران (19) همكاران (Y (Y) يثوهشگران ذكر شده بر اين باورند كه درمان خودنظم جويى هيجانى قابليت و توانيى لازم جهت بهبود مؤلفهاى روانشناختى و هيجانى بيماران را دارد. در تبيين يافته حاضر مبنى بر تأثير درمان خودنظمجويى هيجانى منجر به بهبود مهارتهاى ذهن آكاهى افراد مبتلا

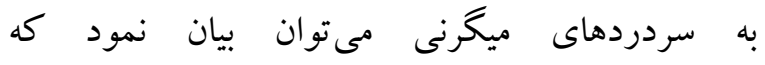
خودنظم جويى هيجانى به معناى كاهش و مهار هيجانات منفى و نحوه استفاده مثبت از هيجانات است (كروس،

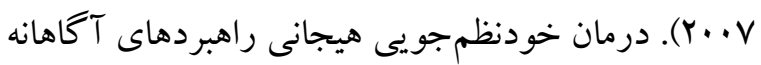
و غير آكاهانهاى را به افراد مى آموزد كه براى افزايش،

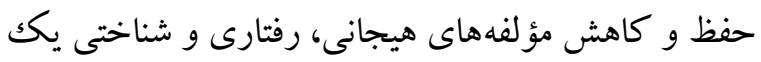
ياسخ هيجانى بكار برده مىشود. پياسخهاى هيجانى

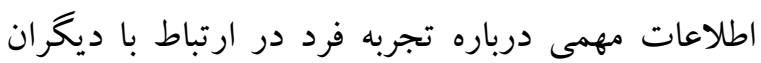
فراهم مى كند. با اين اطلاعات افراد مبتلا به سردردهاى

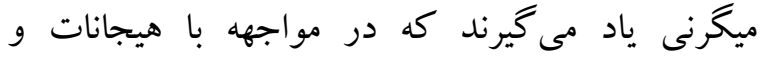
واكنشهاى فيزيولوزيكى همجيون درد جه واكنشى نشان دهند، جِكونه تجارب هيجانى را به صورت كلامى بيان كنند، جهه راهكارهايى را در باسخ به هيجانات بكار برند و در زمينه هيجانهاى خاص جگگ نه با ديخران رفتار كنند. درمان خودنظمجويى هيجانى سبب مىشود، افراد مبتلا به سردردهاى ميخرنى ضمن بذيرش هيجانات خود به 
Andrei F, Nuccitelli C, Mancini G. Reggiani GM, Trombini E. (2019). Emotional intelligence, emotion regulation and affectivity in adults seeking treatment for obesity. Psychiatry Research, 269, 191-198.

Asli Azad M, Manshaei G, Ghamarani A. (2019). The Effect of Mindfulness Therapy on Tolerance of Uncertainty and Thought-Action Fusion in Patients with Obsessive-Compulsive Disorder. Jcmh, 6(1), 83-94. (In Persian).

Azam MA, Katz J, Mohabir V, Ritvo P. (2016). Individuals with tension and migraine headaches exhibit increased heart rate variability during post-stress mindfulness meditation practice but a decrease during a post-stress control condition - A randomized, controlled experiment. Intemational Joumal of Psychophysiology, 110, 66-74.

Baer RA, Smith GT, Allen KB. (2004). Assessment of mindfulness by self-reports the Kentucky inventory of mindfulness skills. Assessment, 11(3), 191-206.

Baer RA, Smith GT, Hopkins J, Krietemeyer J, Toney L. (2006). Using selfreport assessment methods to explore facets of mindfulness. Assessment, 13, 27-45.

Benfer N, Bardeen JR, Clauss K. (2018). Experimental manipulation of emotion regulation selfefficacy: Effects on emotion regulation ability, perceived effort in the service of regulation, and affective reactivity. Journal of Contextual Behavioral Science, 10, 108-114.

Bohm PE, Stancampiano FF, Rozen TD. (2018). Migraine Headache: Updates and Future Developments. Mayo Clinic Proceedings, 93(11), 1648-1653.

Dehghani M, Ismailis N, Akbari F, Hassanvand M, Nikmanesh E. (2014). Investigating the Psychological Characteristics and Factor Structure of the Five-Face Mindfulness Questionnaire, Joumal of Thought and Behavior, 9(33), 11-23. (In Persian).

Dehghani Y,Hekmatianfard A, Kamran L. (2019). The Effectiveness of Emotional Regulation Training on Improving Adaptability and Social Sufficiency of Students with Leaming

$$
\begin{aligned}
& \text { عدم بهره گيرى از روش نمونه گيرى تصادفى و عدم }
\end{aligned}
$$

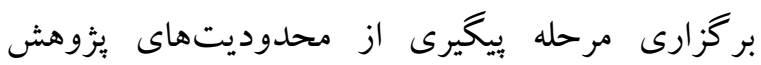

$$
\begin{aligned}
& \text { حاضر بود؛ بنابراين بيشنهاد مى شود براى افزايش قدرت } \\
& \text { تعميميذيرى نتايج، در سطح بيشنهاد بئوهشى، اين } \\
& \text { يزوهش در ساير شهرها و مناطق و جوامع داراى } \\
& \text { فرهنگ هاى متفاوت، ديخر جامعهاى آمارى نظير } \\
& \text { بيماران تالاسمى، سرطان، اماس و .... مهار عوامل ذكر } \\
& \text { شده، بهره گيرى از روشهاى نمونه گيرى تصادفى و } \\
& \text { برگز ارى مرحله ييخيرى اجرا شود. } \\
& \text { سياسگز ارى } \\
& \text { بدين وسيله از تمام بيماران حاضر در بئوهش و مسئولين } \\
& \text { مراكز درمانى افراد مبتلا به سردردهاى ميخرنى در شهر } \\
& \text { زنجان كه همكارى كاملى جهت اجراى بثزوهش داشتند، }
\end{aligned}
$$

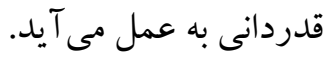

\section{References}

Ahmadi Bajestani BS, Asghari Ebrahimabad MJ, Kimiaei SA, Salayani F. (2018). The Effect of Emotional Focus Therapy (EFT) on Improving Emotional Expression and Improving the Sexual Activity of Women with Type 2 Diabetes. Joumal of Thought and Behavior in Clinical Psychology, 13(50), 5647. (InPersian).

Ahmadi G, Sohrabi F, Borjali A. (2018). The Effectiveness of Emotional Regulation Training on Reassessment and Emotional Depression of Soldiers with Opioid Drug Abuse, Quarterly Joumal of Counseling and Psychotherapy Culture, 9(34), 209-191. (In Persian).

Almarzooqi S, Chilcot J, McCracken LM. (2017). The role of psychological flexibility in migraine headache impact and depression. Joumal of Contextual Behavioral Science, 6(2), 239-243. 
Disabilities, Journal of Applied Psychology, 13(2), 229-250. (In Persian).

Ellis AJ, Salgari G, Miklowitz D, Loo SK. (2018). Is distress tolerance an approach behavior? An examination of frontal alpha asymmetry and distress tolerance in adolescents. Psychiatry Research, 267, 210-214.

Esmaeili Nasab M, Andami Khoshk A, Azarmi H, Samarrokhi A. (2013). The role of difficulty in predicting the regulation of excitement and tolerance of anxiety in students' addiction. Journal of Addiction Abuse of Substance Abuse, 8(29), 63-49.(In Persian).

Farhadi T, Asli Azad M, Shokrkhodaei N. (2018). Effectiveness of mindfulness therapy on executive functions and cognitive fusion of adolescents with obsessive-compulsive disorder, Journal of Exceptional Children Empowerment, 9(4), 81-92. (In Persian).

Havaiy A, Kazemi H, Habibollahi A, Izadikhah Z (2017). The Effect of Emotion Regulation on the Amount of Tension Tolerance and Emotion Regulation Difficulties in Women with Tension-type Headaches. JSSU, 24(10), 840-851. (In Persian).

Herwig U, Opialla S, Cattapan K, Wetter TC, Jäncke L, Brïhl AB. (2018). Emotion introspection and regulation in depression. Psychiatry Research: Neuroimaging, 277, 7-13.

Hofmann SG, Angelina F, Gomez BA. (2017). Mindfulness-Based Interventions for Anxiety and Depression, Psychiatric Clinics of North America. 40(4), 739-749.

Hopwood TL, Schutte S. (2017). A meta-analytic investigation of the impact of mindfulnessbased interventions on post traumatic stress. Clinical Psychology Review. 57, 12-20.

Joormann J, Stanton CH. (2016). Examining emotion regulation in depression: A review and future directions. Behavior Research and Therapy, 86,35-49.

Karami R, Sharifi T, Nikkhah M, Ghazanfari A. (2019). The Effectiveness of Grass-Based EmotionBased Emotion Training on Reducing Mental Disorder and Social Anxiety in 60-Day-Old Girl Students. Iranian Joumal of Health
Education and Health Promotion, 7(1), 1-9. (In Persian).

Keough ME, Riccardi CJ, Timpano KR, Mitchell MA, Schmidt NB. (2010). Anxiety Symptomatology: The Association with Distress Tolerance and Anxiety Sensitivity. Behavior Therapy, 41(4), 567-574.

Kirwan M, Pickett SM, Jarrett NL. (2017). Emotion regulation as a moderator between anxiety symptoms and insomnia symptom severity. Psychiatry Research, 254, 40-47.

Kraaij V, Garnefski N. (2019). The Behavioral Emotion Regulation Questionnaire: Development, psychometric properties and relationships with emotional problems and the Cognitive Emotion Regulation Questionnaire. Personality and Individual Differences, 137, 56-61.

KroskaEB, Miller ML, Roche AI, Kroska SK, O’Hara MW. (2018). Effects of traumatic experiences on obsessive-compulsive and intemalizing symptoms: The role of avoidance and mindfulness. Joumal of Affective Disorders, 225, 326-336.

Lambert GA, Zagami AS. (2018). Does somatostatin have a role to play in migraine headache? Neuropeptides, 69, 1-8.

Lee FKS, Zelman DC. (2019). Boredom proneness as a predictor of depression, anxiety and stress: The moderating effects of dispositional mindfulness. Personality and Individual Differences, 146, 68-75.

Li D, Li D, Wu N, Wang Z. (2019). Intergenerational transmission of emotion regulation through parents' reactions to children's negative emotions: Tests of unique, actor, partner, and mediating effects. Children and Youth Services Review, 101, 113-122.

Malesza M. (2019). Stress and delay discounting: The mediating role of difficulties in emotion regulation. Personality and Individual Differences, 144, 56-60.

Manning K, Rogers AH, Bakhshaie J, Hogan JBD, Buckner JD, Ditre JW, Zvolensky MJ. (2018). The association between perceived distress tolerance and cannabis use problems, cannabis 
withdrawal symptoms, and self-efficacy for quitting cannabis: The explanatory role of pain-related affective distress. Addictive Behaviors, 85, 1-7.

Miller CJ, Brooker B. (2017). Mindfulness programming for parents and teachers of children with ADHD. Complementary Therapies in Clinical Practice, 28, 108-118.

Najarzadegan F, Farhadi H. (2019). The Effect of Quality of Life Therapy on Communication Skills, Addiction to Cyberspace, Marital Satisfaction and Emotional Self-Regulation in Couples, Joumal of Psychological Sciences, 18(74), 247-256.(In Persian).

O’Toole MS, Renna ME, Mennin DS, Fresco DM. (2019). Changes in Decentering and Reappraisal Temporally Precede Symptom Reduction During Emotion Regulation Therapy for Generalized Anxiety Disorder With and Without Co-Occuming Depression. Behavior Therapy, Available online 4 January, InPress, Corrected Proof.

Peraza N, Smit T, Garey L, Manning K, Buckner JD, Zvolensk MJ. (2019). Distress tolerance and cessation-related cannabis processes: The role of cannabis use coping motives. Addictive Behaviors, 90, 164-170.

Renna ME, Quintero JM, Soffer S, Pino M, Ader L, Fresco DM, Mennin DS. (2018). A Pilot Study of Emotion Regulation Therapy for Generalized Anxiety and Depression: Findings From a Diverse Sample of Young Adults. Behavior Therapy, 49(3), 403-418.

Segal ZV, Williams JMG, Teasdale JD. (2013). Mindfulness-based cognitive therapy for depression (2nd ed.). New York: Guilford.

Shamli L, Mehrabi Zadeh Honarmand M, Naami A, Davoodi I. (2018). The effectiveness of emotion-focused therapy on the styles of emotion regulation and the severity of obsessive-compulsive symptoms in women with obsessive-compulsive disorder, Iranian Journal of Psychiatry and Clinical Psychology, 24(4), 356-369. (In Persian).

Shams J, Azizi A, Mirzaei A. (2009). Investigating the relationship between tolerance of confusion and emotional regulation with the degree of students' dependence on smoking. Hakim Research Journal, 11(1), 13-18. (In Persian).

Simons JS, Gaher RM. (2005). The distress tolerance scale: Development and validation of a selfreport measure. Motivation and Emotion, 29(2), 83-102.

Strauss AY, Kivity Y, Huppert JD. (2019). Emotion Regulation Strategies in Cognitive Behavioral Therapy for Panic Disorder. Behavior Therapy, 50(3), 659-671.

Talarska D, Zgorzalewicz-Stachowiak M, Michalak M, Czajkowska A, Hudas K. (2014). Functioning of women with migraine headaches. Scientific World Journal, 492350.

Tomé-Pires C, Solé E, Racine M, Galán S, Castarlenas E, Jensen MP, Miró J. (2016). The relative importance of anxiety and depression in pain impact in individuals with migraine headaches. Scandinavian Joumal of Pain, 13, 109-113.

Wu MF, Yang YW, Chen YY. (2017). The effect of anxiety and depression on the risk of irritable bowel syndrome in migraine patients. Joumal of Clinical Neuroscience, 44, 342-345.

Zvolensky MJ, Bernstein A, Vujanovic AA. (2011). Distress tolerance: Theory, Research, and Clinical Application, New York: Guilford Press. 